\title{
Status Terkini Tutupan Terumbu Karang di Perairan Dangkal Pulau Bedil, Desa Labuan Bajo, Kabupaten Sumbawa, NTB
}

\section{Current Status of Coral Reef Cover in Shallow Waters around Bedil Island, Labuan Bajo Village, Sumbawa Regency, NTB}

\author{
Mahardika Rizqi Himawan $^{1 *}$, Eni Hidayati ${ }^{2}$, Nurliah Buhari ${ }^{1}$, Sitti Hilyana ${ }^{1}$, \\ Maulita Syahdina ${ }^{1}$ \\ ${ }^{1)}$ Program Studi Ilmu Kelautan, Jurusan Perikanan dan Ilmu Kelautan, Fakultas Pertanian UNRAM \\ ${ }^{2)}$ Program Studi Kehutanan, Jurusan Kehutanan, Fakultas Pertanian UNRAM \\ *Corresponding Author Email: mahardika@unram.ac.id
}

Manuscript received: 09-08-2021. Accepted: 27-10-2021

\begin{abstract}
ABSTRAK
Pulau Bedil termasuk dalam Taman Pulau Kecil Keramat, Bedil dan Temudong yang disahkan oleh Bupati Sumbawa. Secara administrasi pulau ini masuk dalam kawasan Desa Labuan Bajo, Sumbawa, NTB. Terdapat ekosistem terumbu karang pada perairan ini yang membentuk profil reef flat dan reef slope yang membentang ke arah barat daya dan timur laut. Sesuai peruntukannya sebagai taman pulau kecil, terumbu karang di perairan Pulau Bedil dimanfaatkan sebagai lokasi pariwisata bawah air. Penelitian ini bertujuan untuk mengetahui kondisi terkini tutupan terumbu karang di perairan sekitar Pulau Bedil terutama pada bagian timur dan selatan pulau. Terumbu karang di bagian utara dan barat minim serta terdapat eksistensi padang lamun. Metode line intercept transect dilakukan dengan membentangkan roll meter sejauh 50 meter pada sisi timur dan selatan pulau dengan kedalaman 2-3 meter. Bentuk pertumbuhan karang yang bersinggungan dengan roll meter kemudian dicatat dan selanjutnya dilakukan analisa persen penutupan rata-rata, klasterisasi status dan indeks mortalitas karangnya. Terumbu karang pada bagian timur dan selatan Pulau Bedil termasuk dalam klasterisasi sangat baik/excellent karena memiliki nilai persen penutupan diatas $75 \%$. Selain itu, nilai indeks mortalitas karang juga tergolong kecil yang menunjukkan karang hidup dengan baik. Kondisi perairan yang jernih dan lokasi yang jauh dari pemukiman manusia diduga menjadi faktor pendukung kelangsungan hidup karang. Meski demikian, keberadaan dead coral alga dan rubble masih menunjukkan adanya ancaman kerusakan meskipun bernilai kecil. Hidupnya alga pada permukaan karang mati juga menunjukkan karang tersebut telah mati pada waktu yang cukup lama.
\end{abstract}

Kata kunci: terumbu karang; line intercept transect; persen penutupan; indeks mortalitas karang 


\begin{abstract}
Bedil Island is included in the Keramat, Bedil, and Temudong Small Island Park (TPK), which was approved by the Regent of Sumbawa. Administratively, this island is included in the Labuan Bajo Village area, Sumbawa, NTB. There is the existence of coral reef ecosystems in these waters that form a reef flat and reef slope profile, that stretches to the southwest and northeast. By its designation as a small island park, the coral reefs in Bedil Island are used as an underwater tourism object. This study aims to determine the current condition of coral reef cover in the waters around Bedil Island, especially in the eastern and southern parts of the island. Coral reefs in the north and west area are limited and there is the existence of seagrass beds. The line intercept transect method is carried out by spreading the roll meter as far as 50 meters on the east and south sides of the island with a depth of 2-3 meters. The coral lifeform that is tangent with the roll meter is then recorded and then analyzed for the average percent cover, clustering status, and coral mortality index. Coral reefs in the eastern and southern parts of Bedil Island are classified as very good/excellent because they have a percent cover value above $75 \%$. In addition, the coral mortality index value is also relatively small which indicates that the corals are living well. Clearwater conditions and locations far from human settlements are thought to be factors that support coral survival. However, the presence of dead coral algae and rubble still indicates a threat of damage even though the value is small. Algae life on the surface of dead coral also indicates that the coral has been dead for a long time.
\end{abstract}

Keywords: coral reef; line intercept transect; percent cover; coral mortality index

\title{
PENDAHULUAN
}

Pulau Bedil, secara administrasi masuk dalam kawasan Desa Labuan Bajo, Kecamatan Utan. Kabupaten Sumbawa, NTB. Melalui Surat Keputusan Bupati Sumbawa No.1198 Tahun 2014, pulau ini termasuk dalam KKPD (Kawasan Konservasi Perairan Daerah) Kabupaten Sumbawa, bersama dengan Pulau Keramat dan Temudang dalam bentuk Taman Pulau Kecil (TPK). TPK tersebut dikenal dengan nama Kabete (Keramat, Bedil dan Temudong). Target konservasi bioekologis dari TPK Kabete sendiri adalah ekosistem mangrove, padang lamun dan terumbu karang (Dermawan et al., 2014).

Pulau Bedil memiliki luas 1,92 hektar dan memiliki ekosistem padang lamun seluas 5,1 hektar serta ekosistem terumbu karang seluas 55 hektar (Dermawan et al., 2014). Ekosistem terumbu karang menjadi ekosistem pesisir yang terluas dan mangrove tidak ditemukan di pulau ini. Dengan statusnya sebagai TPK, terumbu karang di Pulau Bedil dimanfaatkan sebagai objek wisata bawah air selain untuk tempat memancing.

Ekosistem terumbu karang merupakan ekosistem yang memiliki nilai ekologis sebagai penyangga biota di pesisir dan lautan (Bengen, 2020). Ekosistem ini juga bermanfaat dalam memelihara kelestarian dan kehidupan di lautan (White et al., 2000). Terumbu karang selain memiliki nilai ekologi tinggi juga mempunyai nilai ekonomi yang tinggi pula di Indonesia karena pemanfaatanya oleh sebagian masyarakat (Emor 1993). Pemanfaatan tersebut dapat berupa sumberdaya ikan untuk konsumsi maupun pariwisata. Namun, terumbu karang memiliki ancaman kerusakan. Kerusakan tersebut dominan diakibatkan oleh aktivitas manusia yang merusak termasuk kegiatan perikanan yang tidak bertanggung jawab (Tonin, 2018).

Melalui penelitian yang dilakukan oleh Pusat Pengkajian Oseanografi (P2O) Lembaga Ilmu Pengetahuan Indonesia (LIPI, 2008), kondisi terumbu karang di perairan Indonesia memiliki kategori sangat baik sebesar 5,48\%, baik 25,48\%, sedang 37,06\%, dan rusak 31,98\% . Kondisi sedang dan rusak yang memiliki nilai persentase lebih tinggi dibandingkan kategori 
sangat baik dan baik, menunjukkan bahwa terumbu karang Indonesia cukup mencemaskan. Tingginya ancaman yang mempengaruhi penurunan level kondisi terumbu karang tergambarkan dalam hasil penelitian tersebut. Tarigan et al., 2017, melalui 46 titik penelitian terumbu karang yang dilakukan di Kabupaten Sumbawa Barat, Sumbawa, Dompu dan Bima, menujukkan bahwa 32 titik berkategori merah, 6 titik berkategori kuning dan 8 titik berkategori merah. Hal ini juga menunjukkan bahwa kondisi terumbu karang dalam kondisi yang menghawatirkan.

Penelitian ini penting dilakukan untuk mengetahui kondisi terkini tutupan terumbu karang yang ada di Pulau Bedil, yang termasuk dalam TPK Kabete sehingga dapat menjadi referensi dalam penilaian dan upaya rehabilitas terumbu karang secara lokal maupun nasional di Indonesia. Pemanfaatannya sebagai wisata tentu memerlukan informasi terumbu karang sebagai objek utama di pulau ini sebagai dasar penentuan kebijakan dan strategi pengelolaannya.

Tujuan dari penelitian ini adalah untuk mengetahui status terkini kondisi ekosistem terumbu karang melalui persentase penyusun tutupun dasar perairan dangkal di Pulau Bedil, Desa Labuan Bajo, Kabupaten Sumbawa, NTB.

\section{BAHAN DAN METODE}

Waktu, Kondisi, dan Lokasi Penelitan

Penelitian dilakukan pada Tanggal 4 Agustus 2021 pada pukul 10.00-15.00 WITA di perairan Pulau Bedil, Desa Labuan Bajo, Kabupaten Sumbawa, NTB (Gambar 1). Pengambilan data dilakukan di bagian selatan dan timur pulau, karena terdapat eksistensi ekosistem terumbu karang di dasar perairannya. Keberadaan terumbu karang cenderung sangat sedikit pada bagian barat dan utara. Koordinat pengambilan data disajikan Tabel 1.

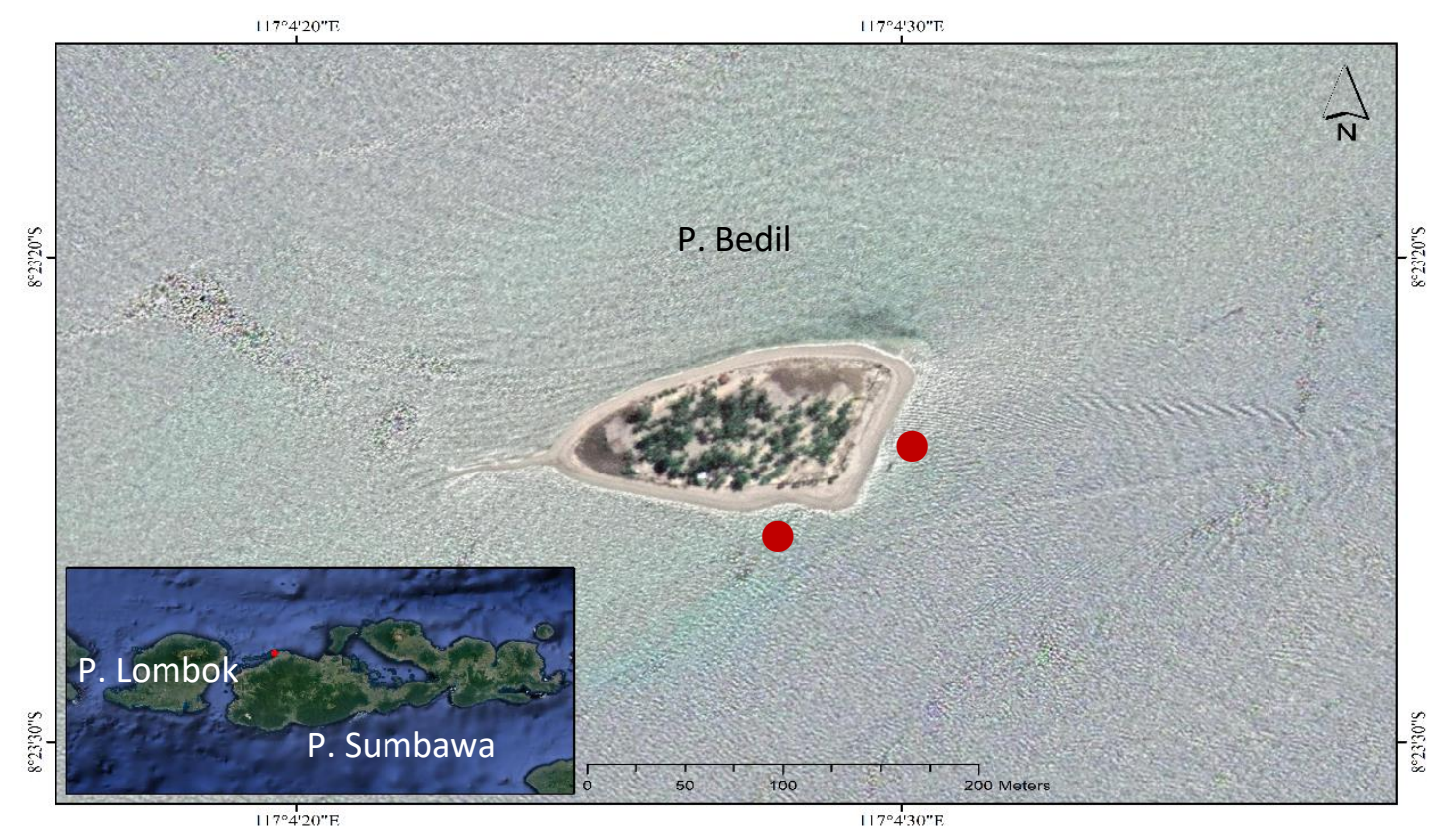

Gambar 1. Lokasi penelitian. (•) = Titik stasiun pengambilan data 
Tabel 1. Koordinat posisi pada setiap stasiun penelitian

\begin{tabular}{|c|c|c|}
\hline Zona & Koordinat & Keterangan \\
\hline Bagian Timur Pulau & $\begin{array}{l}-8^{\circ} 23^{\prime} 24.06 " \mathrm{~S} \\
117^{\circ} 4^{\prime} 29.88^{\prime \prime} \mathrm{E}\end{array}$ & $\begin{array}{l}\text { Stasiun Pengambilan data } \\
\text { terumbu karang } \\
\text { kedalaman 2-3 meter }\end{array}$ \\
\hline Bagian Selatan Pulau & $\begin{array}{l}-8^{\circ} 23^{\prime} 25.49^{\prime \prime S} \\
117^{\circ} 4^{\prime} 27.81^{\prime \prime E}\end{array}$ & $\begin{array}{l}\text { Stasiun Pengambilan data } \\
\text { terumbu karang } \\
\text { kedalaman 2-3 meter }\end{array}$ \\
\hline
\end{tabular}

\section{Metode}

Metode Line Intercept Transect (LIT) (English et al., 1997) dengan penyelaman bawah laut dilakukan dengan membentangkan roll meter pada dasar perairan sepanjang 50 meter $(5.000 \mathrm{~cm}$ ) di titik stasiun pengambilan data (lihat Gambar 1). Selanjutnya, titik awal bentangan transek dicatat koordinatnya menggunakan GPS (Global Positioning System) dan depth gauge digunakan untuk estimasi kedalaman perairan. Kedalaman perairan dalam pengambilan data adalah antara 2-3 meter. Jenis-jenis substrat penyusun dasar perairan yang bersinggungan dengan bentangan transek kemudian diidentifikasi dan dilakukan pencatatan, termasuk panjang singgungannya pada lembar data yang kedap air. Jenis/kategori substrat dasar perairan mengacu pada English et al. (1997)(Tabel 2).

Tabel 2. Jenis/kategori substrat dasar perairan

\begin{tabular}{llcl}
\hline \multicolumn{1}{l}{ Bentuk Petumbuhan (Life form) } & Kode & \multicolumn{1}{c}{ Keterangan } \\
\hline Dead Coral & & DC & Karang yang baru mati, berwarna putih \\
\hline Dead Coral with Algae & DCA & Karang mati yang ditumbuhi alga \\
\hline Hard Coral: & & & \\
Acropora & Branching & ACB & Bercabang seperti ranting. \\
& Encrusting & ACE & Bentuk merayap, seperti Acropora yang \\
& Submassive & ACS & Bercabang lempeng dan kokoh. \\
& Digitate & ACD & Percabangan rapat seperti jari tangan. \\
& Tabulate & ACT & Percabangan arah mendatar. \\
Non Acropora & Branching & CB & Bercabang seperti ranting pohon. \\
& Encrusting & CE & Bentuk merayap, menempel pada substrat. \\
& Foliose & CF & Bentuk menyerupai lembaran. \\
& Massive & CM & Bentuk seperti batu besar. \\
& Submassive & CS & Bentuk kokoh dengan tonjolan. \\
& Millepora & CMR & Bentuk seperti jamur, soliter. \\
& CME & Semua jenis karang api, warna kuning diujung \\
& & & koloni. \\
Other Fauna: & & CHL & Karang biru, adanya warna biru pada skeleton. \\
Soft Coral & & & \\
Sponge & & SC & Karang dengan tubuh lunak \\
Zoanthids & & SP & Contoh: Aaptos aaptos \\
\hline Others: & & ZO & Contoh: Palythoa tuberculosa \\
& & & Anemon, teripang, gorgonian, kima
\end{tabular}




\begin{tabular}{llcl}
\hline Bentuk Petumbuhan $($ Life form $)$ & Kode & \multicolumn{1}{c}{ Keterangan } \\
\hline Algae & Algae Assemblage & AA & Terdiri lebih dari satu jenis alga \\
& Coralline Algae & CA & Alga yang mempunyai struktur kapur \\
& Halimeda & HA & Alga dari genus Halimeda \\
& Macroalgae & MA & Alga berukuran besar \\
Abiotic & Turf Algae & TA & Menyerupai rumput-rumput halus \\
& Sand & S & Pasir \\
& Rubble & R & Patahan karang yang berserakan \\
& Silt & SI & Lumpur \\
& Water & WA & Kolom air /celah dengan kedalaman lebih dari \\
& & & 50 cm \\
Other & Rock & RCK & Tapakan karang termasuk batu kapur \\
& & DDD & Data tidak tercatat atau hilang \\
\hline
\end{tabular}

\section{Analis Data}

Analisa data terumbu karang dilakukan untuk mendapatkan persen penutupan setiap jenis substrat dasar perairan yang bersinggungan dengan transek. Persentase penutupan dihitung menggunakan rumus sederhana sebagai berikut (English et al., 1994):

\section{$\mathrm{Li}=\mathrm{Ni} / \mathrm{L} \times 100 \%$}

Keterangan:

$\mathrm{Li} \quad=$ Persentase penutupan jenis $\mathrm{i}$

$\mathrm{Ni} \quad=$ Panjang total $(\mathrm{cm})$ penutupan jenis $\mathrm{i}$

$\mathrm{L} \quad=$ Panjang total transek

Mengacu pada Yap and Gomez (1984), persentase penutupan yang diperoleh kemudian dilakukan klasterisasi sebagai berikut:

- Excellent (Sangat baik), jika bernilai 75-100\%

- Good (Baik), jika bernilai 50-74,9\%

- Fair (Cukup), jika bernilai 25-49,9\%

- Poor (Buruk), jika bernilai 0-24,9\%

Indeks Mortalitas Karang (IMK) selanjutnya dihitung menggunakan rumus sebagai berikut (Gomez and Yap, 1988):

$$
\mathbf{I M K}=\mathbf{A} /(\mathbf{A}+\mathbf{B})
$$

Keterangan:
IMK = Indeks Mortalitas Karang
A $\quad=$ Persentase tutupan karang mati
B $\quad=$ Persentase tutupan karang hidup 


\section{HASIL DAN PEMBAHASAN}

\section{Tutupan Terumbu Karang di Bagian Timur Pulau Bedil}

Karang keras (hard coral) karang yang menutupi dasar perairan dangkal di bagian timur Pulau Bedil memiliki persentase rata-rata sebesar 83\% (Gambar 2). Tutupan tersebut tergolong tinggi dan tersusun atas karang keras dengan tujuh bentuk pertumbuhan yang berbeda. Ketujuh bentuk pertumbuhan tersebut adalah karang dengan kode ACB, CB, CF, CHL, CM, CMR dan CSM (Gambar 3). Karang Acropora Coral Branching (ACB) memiliki nilai persentase penutupan rata-rata tertinggi di bagian timur pulau jika dibandingkan karang hidup lainnya, yaitu $74,48 \%$. Persentase tutupan karang dengan bentuk pertumbuhan lainnya yang juga teramati adalah Coral Branching (CB)(1,50\%), Coral Foliose $(\mathrm{CF})(1,46 \%)$, Coral Millepora (CME)(0,26\%), Coral Massive (CM)(5,06\%), Coral Mushroom (CMR)(0,44\%) dan Coral Submassive (CSM)(0,84\%).

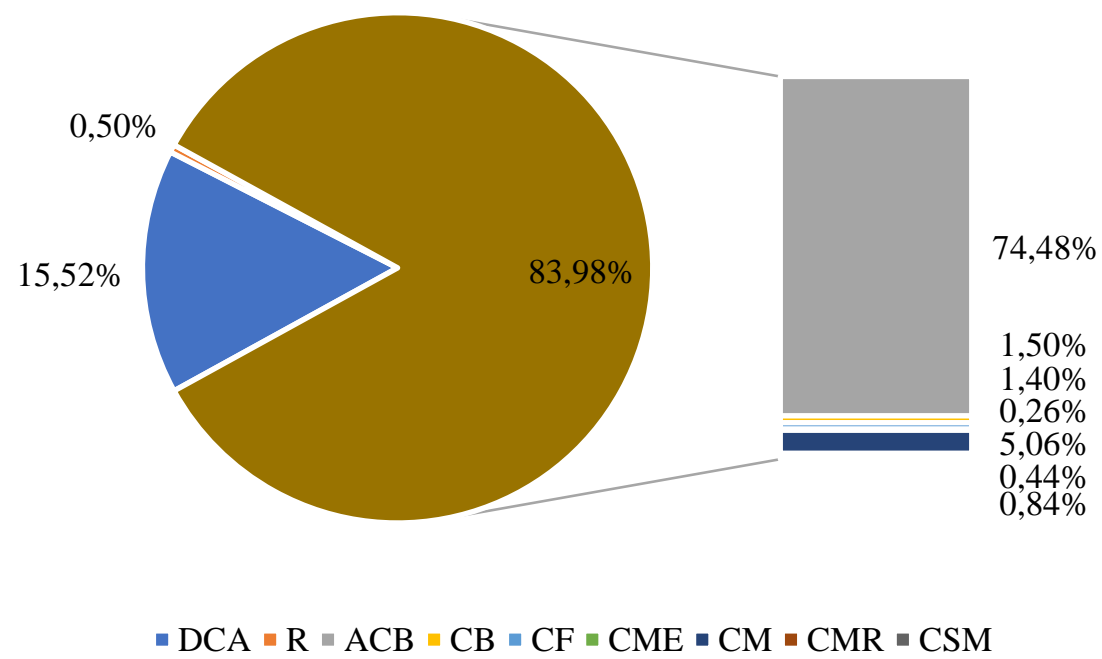

Gambar 2. Persentase tutupan dasar perairan dangkal di bagian Timur Pulau Bedil

Jenis karang keras dengan bentuk pertumbuhan Acropora Coral Branching yang memiliki presentase tutupan rata-rata tertinggi adalah dari genus Acropora sp. Persentase ratarata tutupan dasar perairan selain karang keras adalah Dead Coral Algae (DCA), yaitu sebesar $15 \%$ dan Rubble (R) sebesar 0,50\%. Keberadaan karang mati yang ditumbuhi alga/DCA dan patahan karang berserakan/R memiliki nilai yang lebih kecil dibandingkan dengan karang hidup. Kedua kategori tutupan tersebut diduga merupakan karang hidup di masa lalu yang mengalami kematian. Tumbuhnya alga pada karang mati menunjukkan karang telah mati pada waktu yang cukup lama (Noviana et al., 2018).

Indek Mortalitas Karang pada perairan ini cenderung sangat kecil, yaitu 0,16. Nilai tersebut mendekati 0 yang berarti terumbu karang memiliki rasio kematian yang rendah. English et al., 1997 menyatakan bahwa semakin mendekati nilai 1, maka Indeks Mortalitas Karang akan semakin tinggi. Terumbu karang cenderung tidak memiliki gangguan yang berarti 
dalam siklus kehidupannya. Kondisi tersebut diperkuat dengan status terumbu karang di perairan dangkal bagian timur Pulau Bedil yang tergolong dalam klasterisasi sangat baik (Excellent).

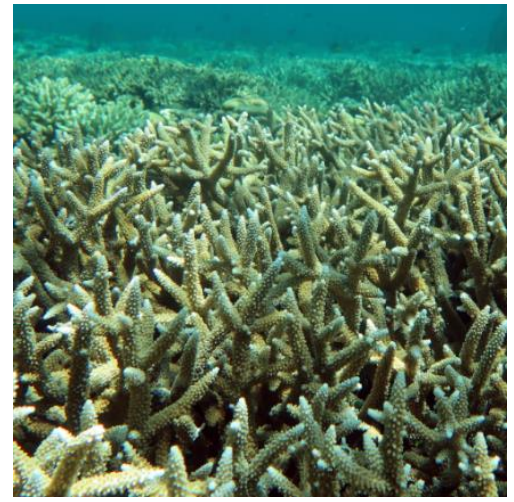

A

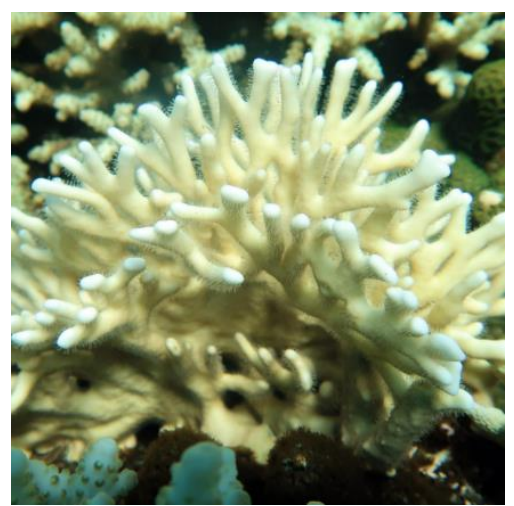

$\mathrm{D}$

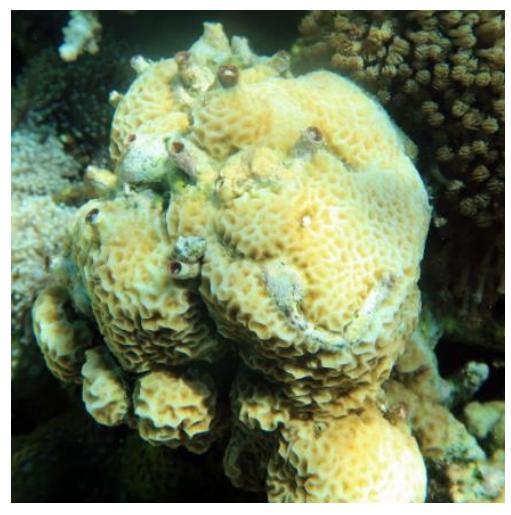

$\mathrm{G}$

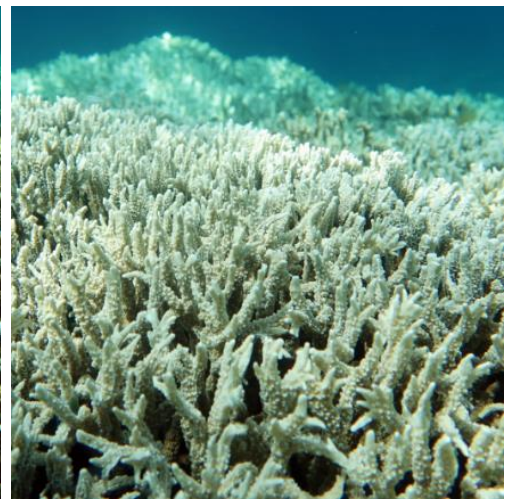

$\mathrm{B}$

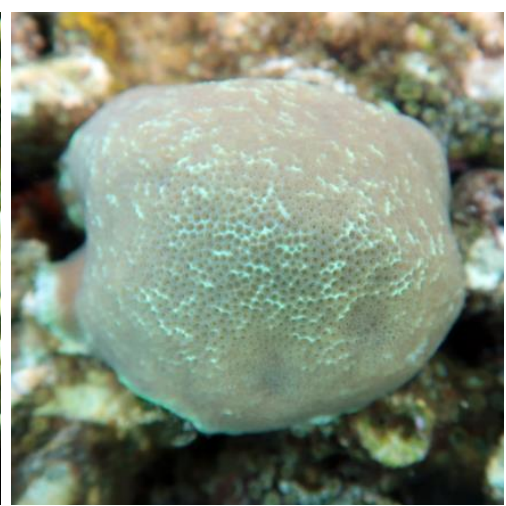

$\mathrm{E}$

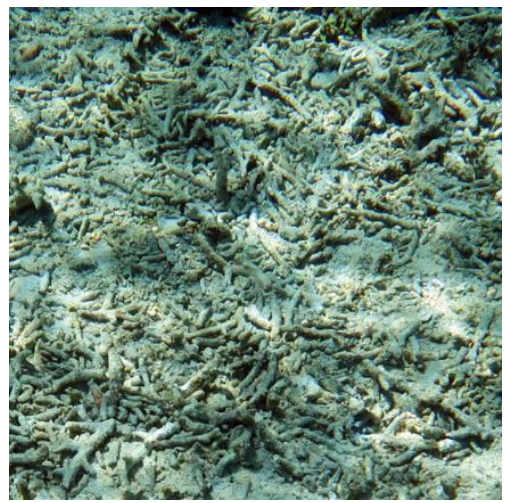

$\mathrm{H}$

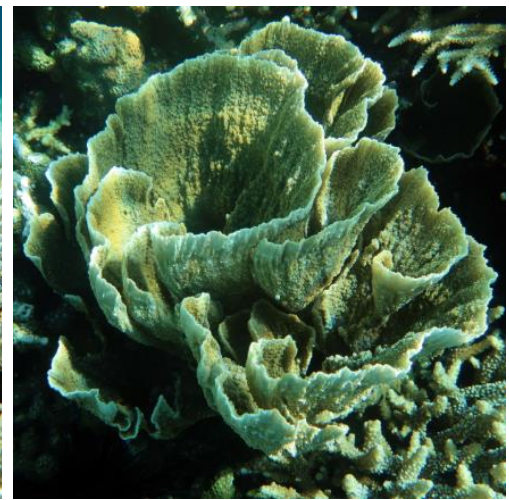

$\mathrm{C}$

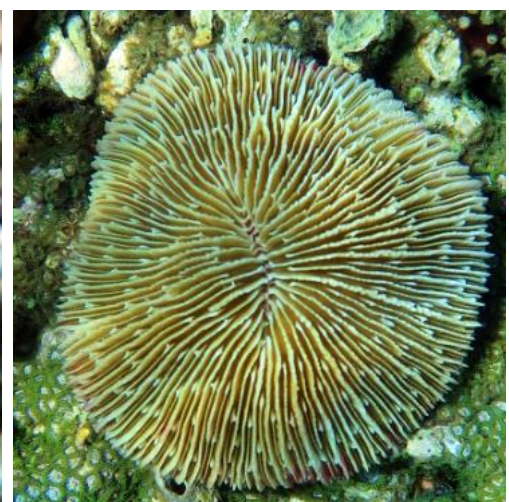

$\mathrm{F}$

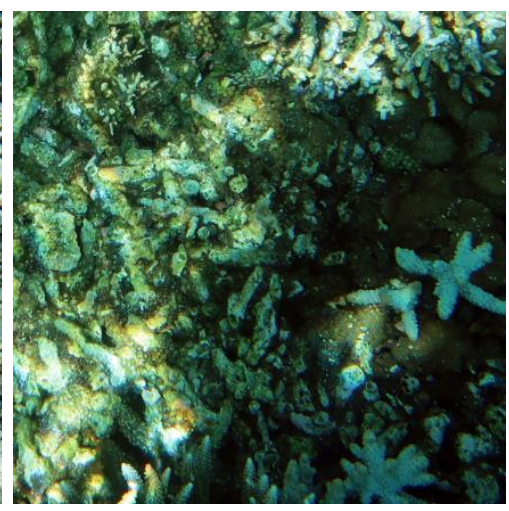

I

Gambar 3. Bentuk pertumbuhan karang dan kategori lainnya yang menyusun tutupan dasar perairan dangkal bagian timur Pulau Bedil: A) ACB, B) CB, C) CF, D) CME, E) CM, F) CMR, G) CSM, H) R, I) DCA

\section{Tutupan Terumbu Karang di Bagian Selatan Pulau Bedil}

Tutupan karang keras di perairan dangkal pada bagian selatan Pulau Bedil memiliki persentase rata-rata sebesar 90,22\% (Gambar 4). Persentase ini memiliki nilai yang lebih tinggi 
dibandingkan di bagian timur. Namun, bentuk pertumbuhan terumbu karang yang menyusun persentase tersebut cenderung lebih sedikit yaitu berjumlah lima bentuk. Bentuk-bentuk pertumbuhan karang yang menyusun adalah ACB, CB, CF, CM dan CMR (Gambar 5). Karang Acropora Coral Branching (ACB) dan Coral Branching (CB) memiliki nilai persentase penutupan rata-rata tertinggi di bagian selatan pulau jika dibandingkan karang hidup lainnya. Kedua bentuk pertumbuhan tersebut memiliki nilai yang cenderung sama, meskipun Coral Branching lebih tinggi 0,26\%, yaitu 39,26\%. Acropora Coral Branching memiliki nilai persentase rata-rata $39,78 \%$. Persentase tutupan karang dengan bentuk pertumbuhan lainnya yang juga teramati adalah Coral Foliose (CF)(9,08\%), Coral Massive (CM)(1,86\%) dan Coral Mushroom (CMR)(0,24\%). Jenis karang keras dengan bentuk pertumbuhan Acropora Coral Branching yang memiliki presentase tutupan rata-rata tertinggi adalah dari genus Acropora sp., sedangkan Coral Branching adalah dari genus Porites sp.

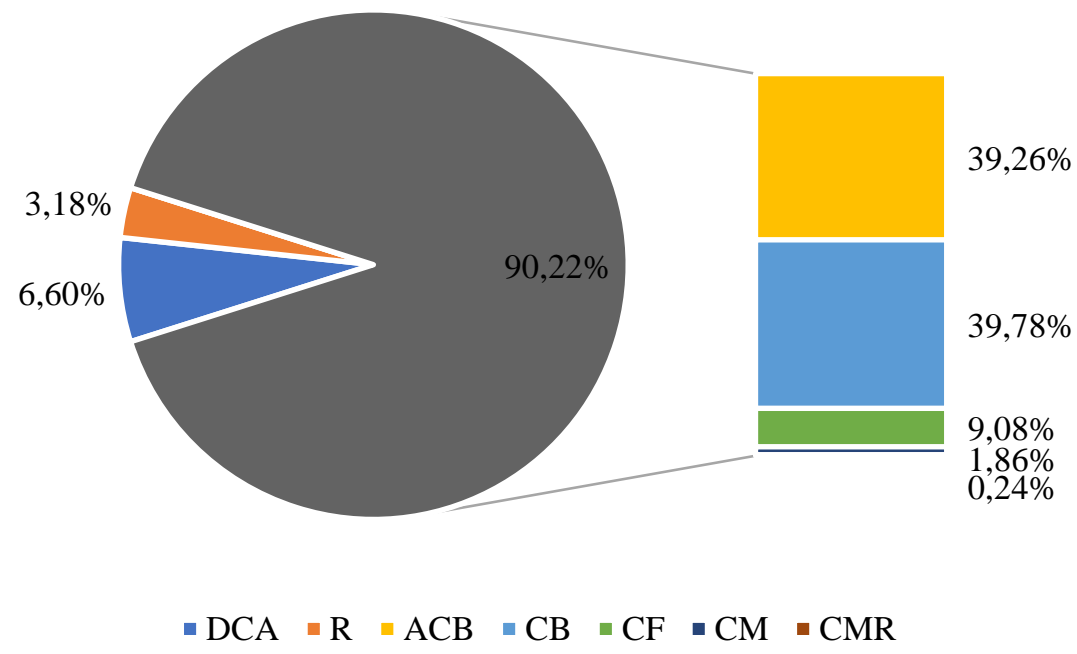

Gambar 4. Persentase tutupan dasar perairan dangkal di bagian Selatan Pulau Bedil

Tutupan dasar perairan dalam bentuk Dead Coral Alga (DCA) dan Rubble (R) memiliki akumulasi persentase rata-rata adalah 9,78\%. Nilai masing-masing persentase tutupan tersebut adalah 6,60\% (DCA) dan 3,18 (R). Keberadaan karang mati diduga akibat aktivitas perikanan yang tidak ramah dan merusak dimasa lampau. Adanya alga yang tumbuh pada karang yang mati juga menjadi indikasi karang mati yang telah berlangsung cukup lama (Noviana et al., 2018). Namun, nilai tersebut tergolong lebih rendah dibandingkan dengan karang hidup dan lebih kecil dibandingkan nilai DCA di bagian timur pulau. Nilai persentase rata-rata karang hidup pada zona ini yang sebesar 90,22\% membuat terumbu karang di perairan ini juga masuk dalam klasterisasi sangat baik (Excellent). Kategori ini berada diantara nilai persentase 75$100 \%$. Indeks Mortalitas Karang bernilai kecil, yaitu 0,10. Nilai tersebut mendekati 0 yang berarti terumbu karang memiliki rasio kematian yang rendah (English et al., 1997). Nilai ini lebih kecil juga dibandingkan dengan bagian timur pulau. 


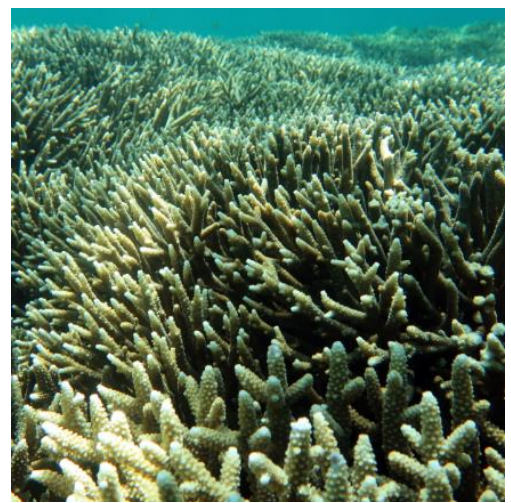

A

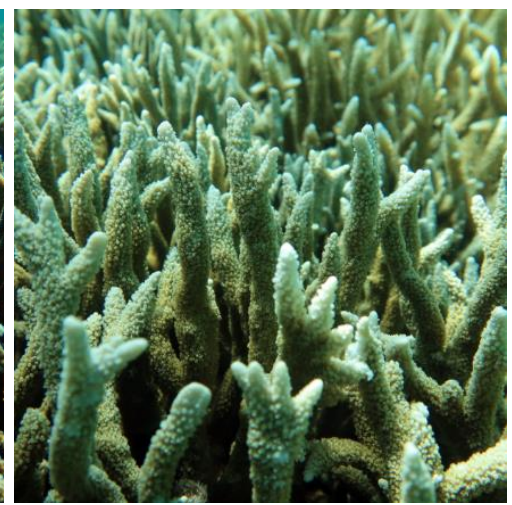

B

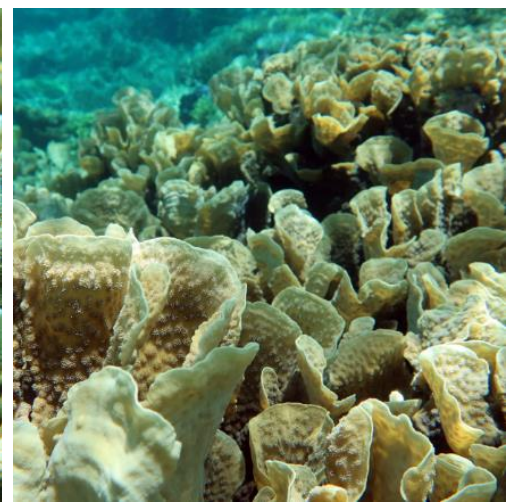

$\mathrm{C}$

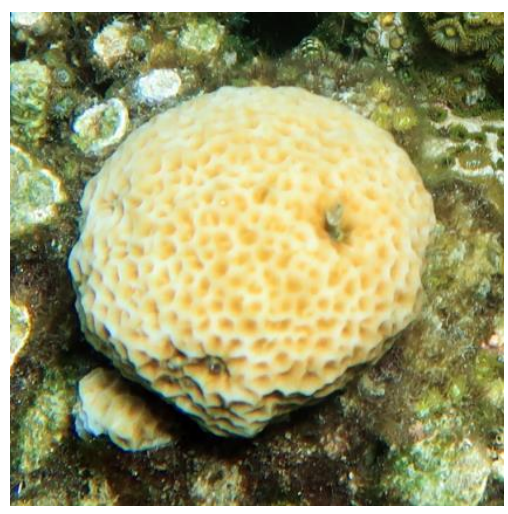

$\mathrm{D}$

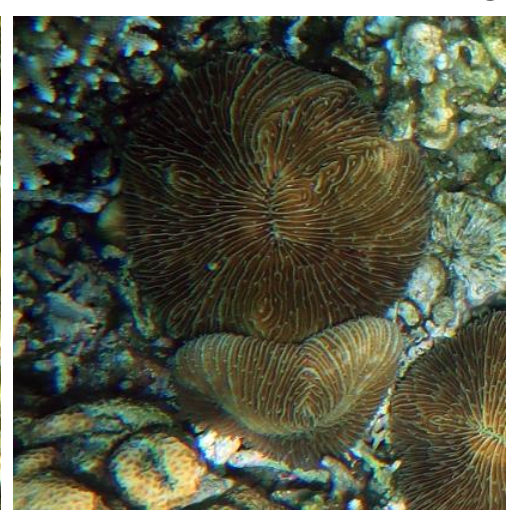

$\mathrm{E}$

Gambar 5. Bentuk pertumbuhan karang yang menyusun tutupan dasar perairan dangkal bagian selatan Pulau Bedil: A) ACB, B) CB, C) CF, D) CM, E) CMR.

\section{Diskusi}

Profil terumbu karang di bagian timur dan selatan Pulau Bedil cenderung membentuk karang datar (reefflat) di sekitar garis pantai dengan kedalaman antara 1-5 meter dan karang lereng/curam (reef slope) ke arah laut lepas. Reef flat adalah struktur hamparan terumbu yang datar dan cenderung berada di kedalaman yang sama secara luas sedangkan reef slope adalah struktur terumbu yang berada di lereng dan memiliki kedalaman berbeda hingga tingkat perbedaan yang ekstrim (Sheppard, 1982). Terumbu karang di pulau ini membentang ke arah badar daya sejauh 750 meter dan timur laut sejauh 450 meter (Dermawan et al., 2014). Keberadan terumbu karang pada bagian utara dan barat tergolong sangat sedikit dan ekosistem padang lamun tumbuh disana.

Karang dengan bentuk pertumbuhan Acropora Coral Branching mendominasi tutupan dasar perairan baik di bagian timur dan selatan pada perairan dangkal antara 2-3 meter. Meskipun demikian, terdapat tutupan Coral Branching yang juga tinggi di bagian selatan. Tutupan dengan nilai persentasi rata-rata diatas $75 \%$ membuat kedua perairan tersebut berada dalam kondisi yang sangat baik. Kleypas et al., 1999 menyatakan bahwa bentuk pertumbuhan, tingkat pertumbuhan dan kemampuan reproduksi terumbu karang dipengaruhi oleh kondisi fisika lingkungan perairan. Kondisi tersebut juga selanjutnya mempengaruhi keanekaragaman 
yang berkembang pada perairan tersebut (Baker et al., 2008). Karang dengan betuk pertumbuhan bercabang maupun masif cenderung berkembang dengan baik pada perairan yang jernih dan berarus karena sirkulasi perairan dengan kandungan unsur haranya yang baik (Panggabean \& Setiadji 2011). Perairan Pulau Bedil cenderung memiliki perairan yang jernih dengan jarak pandang lebih dari 20 meter. Selain itu, pulau ini juga tergolong jauh dari pemukiman manusia.

Persentase rata-rata tutupan bukan karang keras, yaitu Dead Coral Alga dan Rubble di kedua titik pengambilan data memiliki nilai dibawah $16 \%$ yang menandakan terumbu karang hidup mendominasi perairan tersebut. Didukung oleh nilai Indeks Mortalitas Karang yang dibawah nilai 0,16 , menunjukkan bahwa terumbu karang berada dalam kondisi yang baik dan tidak memiliki tekanan yang berarti sehingga berdampak pada potensi kerusakan yang kecil. Namun, keberadaan Dead Coral Alga dan Rubble menunjukkan adanya kerusakan ekosistem terumbu karang meskipun tidak menjadi dominan. Adanya alga yang tumbuh juga mengindikasikan bahwa karang telah lama mati.

\section{KESIMPULAN}

Terumbu karang di perairan dangkal Pulau Bedil pada bagian timur dan selatan memiliki kondisi yang sangat baik dengan dominansi jenis karang dengan bentuk pertumbuhan Acropora Coral Branching. Pada perairan bagian selatan, karang bentuk pertumbuhan Coral Branching juga turut memiliki nilai presentasi yang dominan. Selain itu, nilai Indeks Mortalitas Karang kedua perairan tersebut juga bernilai mendekati nol yang berarti terumbu karang memiliki nilai kelangsungan hidup yang tinggi. Meski demikian eksistensi Dead Coral Alga dan Rubble menjadi indikasi terjadinya kerusakan terumbu karang meskipun memiliki nilai persentase yang kecil. Kematian karang pada masa lalu terjadi dengan adanya alga yang tumbuh pada karang mati.

\section{Ucapan Terimakasih}

Peneliti mengucapkan terima kasih kepada Yayasan Komunitas Penjaga Pulau yang telah memberikan dukungan dalam pelaksanaan penelitian di Pulau Bedil, Kabupaten Sumbawa, NTB.

\section{DAFTAR PUSTAKA}

Baker, A.C., P.W. Glynn, B. Riegl. 2008. Climate change and coral reef bleaching: an ecological assessment of long-term impacts, recovery trends and future outlook. Estuarine, Coastal and Shelf Science: 80: 435-471.

Bengen, D. G. 2002. Ekosistem dan Sumberdaya Alam Pesisir dan Laut serta Prinsip Pengelolaannya. Bogor: Pusat Kajian Sumberdaya Pesisir dan Lautan IPB.

Dermawan, A., S. B. Lubis, Suraji, N. Rasyid, M. Ashari, T. Kuhaja, A. Sofiullah, M. Saefudin, A. Setianingrum, K. handadari, R. Widiastutik, D. R.Wulandari. 2014. Status Pengelolaan Efektif Kawasan Konservasi Perairan, Perairan dan Pulau-Pulau Kecil di 
Indonesia: Profil 113 Kawasan Konservasi Perairan, Pesisir dan Pulau-pulau Kecil. Jakarta: Direktorat Konservasi Kawasan dan Jenis Ikan, DJKP3K, KKP.

Emor J.W., 1993. Koresponden antara ekoregion dan pola sebaran komunitas terumbu karang di Bunaken [Tesis]. Program Pascasarjana Institut Pertanian Bogor: Bogor.

English. S, C. Wilkinson, V. Baker. 1997. Survey Manual for Tropical Marine Resources. Townsville, Australia, Australian Institute of Marine Science: Townsville Australia.

Gomez, E.D., H.T. Yap. 1998 Monitoring Reef Condition. In R.A. Kenchington and B.E.T. Hudson (Eds). Coral Reef Management Handbook. Unesco Regional Office For Science and Technology for Southeast Asia: Jakarta

LIPI. 2008. Kondisi sebaran terumbu karang di Indonesia. LIPI: Jakarta.

Noviana L., H.S. Arifin, L. Adrianto, Kholil. 2018. Studi ekosistem terumbu karang di Taman Nasional Kepulauan Seribu. Journal of Natural Resources and Environmental Management: 9(2):352-365.

Panggabean A.S., B. Setaidji. 2011. Bentuk pertumbuhan Karang Daerah Tertutup Dan Terbuka Di Perairan Sekitar pulau Pamegaran, Teluk Jakarta. Bawal, 3 (4):255-260.

Sheppard C.R.C. 1982. Coral Populations on Reef Slopes and Their Major Controls. Mar. Ecol. Prog. Ser. 7: 83-115. 1982

Surat Keputusan Bupati Sumbawa No.1198 Tahun 2014 Mengenai Pengelolaan Kawasan Konservasi Perairan Daerah Kabupaten Sumbawa Taman Pulau Kecil Kramat, Bedil, Temudong (TPK Kabete).

Tarigan S.A., S. Pardede, S. Aviandhika, Hernawati, Hotmariyah, Suniri, W. T. Surjadi, E. S. Saha, F. Ardiyansyah. 2017. Status Ekosistem Terumbu Karang Di Nusa Tenggara Barat. Disampaikan pada Seminar Nasional Biologi Wallacea Mataram, 8-9 November 2017

Tonin, S. 2018. Economic value of marine biodiversity improvement in coralligenous habitats. Ecological Indicators. 85:1121-1132.

White, A., M. Ross, M. Flores. 2000. Benefits and costs of coral reef and wetland management, Olango Island, Philippines, p. 215-227. In H. Cesar (ed.) Collected essays on the economics of coral reefs. CORDIO, Department for Biology and Environmental Sciences: Kalmar University, Kalmar, Sweden. 